\title{
THE EFFECT OF CLIMATE CONDITIONS IN UZBEKISTAN ON BIOLOGICAL INDICATORS OF CHINESE SILKWORM BREEDS AND HYBRIDS
}

\author{
Oripov Otabek Oripovich \\ Independent researcher, Department of the Sericulture and Mulberry Growing, \\ Tashkent State Agrarian University, Tashkent, Uzbekistan
}

\author{
Umarov Shavkat Ramazanovich \\ Doctor of Agricultural Sciences, Professor of the Department Sericulture and Mulberry Growing, \\ Tashkent State Agrarian University, Tashkent, Uzbekistan
}

Article DOI: https://doi.org/10.36713/epra5764

\begin{abstract}
The article presents thorough analysis results and scientifically proven theoretical data on hatching and care of eggs of imported mulberry silkworm breeds and hybrids at different temperatures and humidity. The aim is to produce silkworm eggs based on the adaptation of imported mulberry silkworms to the rapidly changing natural climate condition of Uzbekistan, to improve the productivity and technological properties of cocoons. Effective scientific solutions for the care of imported eggs have been determined by substantiating effective agrotechnology for silkworm rearing and defining the effect of temperature and relative air humidity at cocoonery and feed amount on biological, cocoon productivity and technological properties of silkworms in the rearing of mulberry silkworm breeds and hybrids imported from abroad, adapted to the conditions of Uzbekistan.
\end{abstract}

KEYWORDS: silkworm eggs, incubation, temperature, humidity, light, mulberry leaves, silkworm, breed, hybrid, cocoonery, truss, pupa, moth, pure cocoon, silk.

\section{INTRODUCTION}

Today, the demand in the world market for cocoon, natural silk and silk fabrics is growing day by day. At present, “...mulberry silkworm eggs are produced in more than 20 countries with developed silk production, and 14.5 million box of silkworm eggs are produced in People's Republic of China, 5.0 million box in India, 300000 boxes in Uzbekistan and the remaining 3.2 million box corresponds to the share of other countries". Uzbekistan is the third largest cocoon producer in the world, achieving an average of $59.0 \mathrm{~kg}$ of cocoons per box of silkworm eggs. The geographical location of Uzbekistan is currently a favorable ecological zone for the cultivation of silkworm, and more than 380-400 thousand boxes of silkworms are annually reared $[8,9]$.
Researches are being carried out around the world to create breeds and hybrids of mulberry silkworms suitable for different regions and to develop and introduce new innovative agro-technologies in silkworm breeding. In this regard, given the global climate change, the creation of breeds and hybrids of mulberry silkworm adapted to rapidly changing and optimal climatic conditions, the development of new intensive technologies for silkworm rearing and the introduction of foreign breeds and hybrids are of great scientific and practical importance $[5,6]$.

Extensive scientific research on the assessment of the impact of the external environment on the important traits and characteristics of mulberry silkworm in our country, the effect of feed amount, quality, air temperature and relative humidity on the growth and 


\section{SJIF Impact Factor: 7.001| ISI I.F.Value:1.241| Journal DOI: 10.36713/epra2016 \\ ISSN: 2455-7838(Online) \\ EPRA International Journal of Research and Development (IJRD)}

development of silkworm and the manifestation of hereditary potential of different breeds and hybrids at different conditions were conducted by U.N. Nasirillaev, N.A. Akhmedov, Sh.R. Umarov, S.S. Lezhenko and B.U. Nasirillaev [4, 5, 6].

Moreover, scientists from the advanced countries with developed cocoon production, A.Z. Zlotin, V.N. Kirichenko, O.Zh. Zhurovl, M.E. Braslavsky, N.A.Begum, M. Rekha, N. Baramidze carried out research work and achieved positive results on the study of resistance of mulberry silkworm to adverse conditions during embryonic development, creation of new breeds using voltinism, as well as, compensation for the harmful effects of adverse conditions through the use of biologically active substances.

Sufficient attention has not been paid yet to scientific research on the creation of specific care and rearing agro-technologies of silkworm focused on the adaptation of imported mulberry silkworm breeds to the conditions of the Republic, production of high-quality pure cocoons, preparation of high-quality silkworm eggs, as well as increasing cocoon productivity and technological properties. Carrying out research work to solve these problems is of great scientific and practical importance [7, 8, 9].

However, certain results are being achieved in the creation of local breeds and hybrids adapted to the specific climatic conditions of the republic. But, as mentioned above, insufficient attention has been paid to the development and scientific substantiation of optimal care agro-technologies aimed at adapting imported mulberry silkworm breeds to the conditions of Uzbekistan, increasing the yield, varietal potential and technological properties of cocoons.

In the decree "About Actions Strategy for development of the Republic of Uzbekistan in 20172021", Presidential decree of the Republic of Uzbekistan from March 29, 2017 "About the measures on the establishment of the activity of "Uzbekipaksanoat" association" numbered-2856 and Presidential decree "About additional measures on further development of sericulture sector" dated March 20, 2018 йил numbered3616, the tasks on extensive testing of selection achievements, developing primary seed breeding of silkworm breeds and hybrids, creation of breeds and hybrids suitable to international requirements through developing advanced scientific elaborations and intensive agro-technologies considering natural climatic conditions of regions, increasing the potential of production of local silkworm and cocoon, as well as export potential of sericulture industry by improving the quality $[1,2,3]$.

\section{MATERIALS AND METHODS}

Experiments on the substantiation of optimal technology for caring and rearing of silkworm (Bombyx mori L.) breeds and hybrids imported from People's Republic of China were conducted in 2013-2018.
Experimental testing on two productive silkworm breeds "Khitoy" and "Yaponiya" imported from China, was performed in the laboratory of "Sericulture and mulberry growing" department of Tashkent state agrarian university, in "Ipak Kurti Urugchiligi”" LLC in Okkurgan district of Tashkent region, in "Ipak Kurti Urugchiligi" LLC in Karmana district of Navoi region and another testing experiment was conducted on "Jigsong $\times$ Haoyue" and "Haoyue $\times$ Jigsong" hybrids imported from People's Republic of China in "Nurli Tong Silk" LLC in Margilan town of Fergana region.

In all research, observations and experiments on the substantiation of the technology of optimal care and rearing of foreign breeds and hybrids of mulberry silkworms, the geographical location of the region, including the mountain and desert zones, and their natural soil-climatic conditions were taken into account.

The selection of regions with different climatic conditions of the republic has made dissertation research more effective and reliable.

Since $70-80 \%$ of silkworm eggs raised in our country are imported from abroad, mainly from the People's Republic of China, foreign industrial hybrids "Jigsong $\times$ Haoyue" and "Haoyue $\times$ Jigsong" were used in our research.

Local silkworm breeds "Asaka" and "Marhamat" as well as hybrids "Ipakchi-1 x Ipakchi-2" that are widely used in the Republic (60-70\%) presently, were used as a comparator.

Mulberry leaves grown on university campus and small experimental farms, as well as in the areas with different soil-climatic conditions, were used as food for silkworms.

In the first part of our experiments, 20 egg batches were taken from each of the eggs laid by female moths of "Khitoy" and "Yaponiya" breeds imported from China and they were left for hatching. Depending on the hatching of caterpillars from the egg batches, 5 variants were prepared from each of the experimental "Khitoy" and "Yaponiya" breeds.

"Asaka" breed zoned in the Republic was chosen as a comparative control for the experimental "Khitoy" breed imported from China. "Markhamat" breed zoned in the Republic was used as a comparative control for "Yaponiya" breed.

In the second part of our experiments, 15 variants from "Jingsong $\times$ Haoyue" and "Haoyue $\times$ Jingsong" hybrids imported from People's Republic of China were made and observed.

Ipakchi-1 $\times$ Ipakchi-2 hybrids zoned in the republic and reared extensively on the farms, were taken as control and comparator for the silkworm hybrids imported from abroad.

Eggs of imported silkworm breeds and hybrids hatched and caterpillars were reared, as well as the moths come out of cocoon mated in the variants at three different temperatures and humidity: 


\section{SJIF Impact Factor: 7.001| ISI I.F.Value:1.241| Journal DOI: 10.36713/epra2016

- in the first experimental testing, temperature was 20-2 $1^{\circ} \mathrm{C}$, humidity $60-65 \%$;

- in the second experimental testing, temperature was $26-27^{\circ} \mathrm{C}$, humidity $75-80 \%$;

- in the third experimental testing, temperature was $28-29^{\circ} \mathrm{C}$, humidity $70-75 \%$. variants:

The following breeds and hybrids were used by China.

Variant 1 - "Yaponiya" breed eggs imported from China.

Variant 2 - "Khitoy" breed eggs imported from

Variant 3 - "Jigsong $\times$ Haoyue" hybrid eggs imported from China.

Variant 4 - "Haoyue $\times$ Jigsong" hybrid eggs imported from China.

Variant 5 - (comparative) Ipakchi-1 $\times$ Ipakchi-2 hybrid eggs made in Uzbekistan.

\section{RESULTS AND DISCUSSION}

The scientific significance of the research results is explained by the fact that the data were theoretically obtained and generalized on scientific substantiation of interdependence of changes in biological attributes (egg hatching, caterpillar survival, larva period, skin peeling, cocoon spinning and etc.), cocoon productivity (cocoon yield and quality, silkiness) and technological attributes (raw silk yield, unwinding cocoon and its metric number), as well as fertility of moths (laying a lot of eggs) on food, environmental and rearing conditions.

On the basis of the research results conducted to substantiate optimal care and rearing technology for imported silkworm (Bombyx mori L.) breeds and hybrids:

Recommendation named "Agrotechnologies for the care for imported silkworm breeds and hybrids in Uzbekistan" has been developed and approved on improving the quality of hybrid eggs produced by imported breeds in the Republic's egg-producing enterprises and cocoon quality of silkworms reared on the farms (Reference of Agriculture Ministry from June 17, 2020 numbered 02/028-1748). As a result, 4.8 grams of additional eggs were produced from one box of 25 boxes of imported pure silkworms, the economic efficiency of one box was 55404.0 soums and the net profit was 21554.0 soums, the profitability increased by $12.7 \%$;

"Yaponiya" silkworm breed imported from China was reared in "Ipak Qurti Urugchiligi" LLC in Karmana district of Navoi region in 21 boxes, one box of imported pure silkworm produced 5,1 grams of additional silkworm eggs, from which economic efficiency made 55606.8 soums, net profit was 22952.3 soums and profitability increased by $14.1 \%$;

Rearing of "Jigsong $\times$ Haoyue" industrial hybrid eggs of 21 boxes of imported silkworm from People's Republic of China was implemented "Nurli Tong Silk"
LLC in Fergana region (Reference of Agriculture Ministry from June 17, 2020 numbered 02/028-1748). In result, one box of introduced hybrid produced 0.89 grams of additional raw silk, while 21 boxes of imported hybrid yielded $18,7 \mathrm{kgs}$ of raw silk after proper care, its economic efficiency made 6025656 soums, profitability increased by $27,6 \%$.

It is known that in recent years, $70-80 \%$ of mulberry silkworm eggs are imported from abroad for the production of 18-20 thousand tons of raw cocoons in the country. However, the average cocoon yield obtained by rearing the caterpillars hatched from these eggs, is no more than $55-57 \mathrm{~kg}$. In order to find out the reason for this, imported and local silkworm breeds and hybrids were selected and accordingly variants were prepared from their eggs. It has been planned to produce abundant best quality yield and to improve technological indicators of cocoon by incubating imported silkworm eggs, caring for hatched larva at different temperatures and humidity, adapting them to the conditions of Uzbekistan and developing agro-technologies for optimal care and rearing of silkworm breeds and hybrids.

Due to the lack of special incubators on farms today, mulberry silkworm eggs are hatched in homes at different temperatures and humidity. Therefore, it was targeted to get the eggs hatched at sharply different temperatures and to determine the amount of hatched larva. When silkworm eggs were hatched at lower temperature $\left(20-21^{\circ} \mathrm{C}\right)$ than in the norm $\left(24-25^{\circ} \mathrm{C}\right)$, incubation period in all variants lasted 13-14 days, larva hatching lasted 4,5-5,5 days. The incubation period usually lasts 10 days at moderate temperatures and the larvae hatch within 3 days. It is obvious that when the temperature is $20-21^{\circ} \mathrm{C}$ during the incubation period, embryonic development is delayed for 3-4 days and larva hatching for 2 days. This leads prolongation of silkworm rearing process, causing the remaining adult worms on hot days when the leaves harden and become rough, and accordingly the yield decreases.

At the same time, the first larva hatching from eggs made $2,0-4,5 \%$, that is, $1,5-4,0 \%$ more than the usual case $(0,2-0,5 \%)$, the amount of hatched eggs on the first day were less by $25-30 \%$ compared to hatching rate of larva under moderate temperature, on the second day by $6,0-13,0 \%$, on the third day contrarily, they hatched more by $13-17 \%$, on the fourth day by $6,0-13 \%$. Total amount of hatched larva of "Yaponiya" breed constituted $89,5 \%(\mathrm{Pd}=0,999)$, in "Khitoy" breed $91 \%(\mathrm{Pd}=0,807)$, in Chinese hybrids and control variant 93\%, showing 2,0-3,5\% lower hatching than the hatching rate of moderate condition (Table 1).

When incubation process was performed under moderate condition (temperature $24-25^{\circ} \mathrm{C}$ and humidity $75-80 \%$ ), incubation period lasted for 10 , first hatched larva was $0,5-1,5 \%$, larva come out of eggs during 3 days. On the $1-2$ nd days $87-93 \%$ larva hatched, on the 3rd day 2,5-3,0\%. This rate was 6-7 \% for "Khitoy" and 


\section{EPRA International Journal of Research and Development (IJRD)}

"Yaponiya" breeds. Total egg hatching was equal to $95,5-97,5 \%$ that was found to correspond to the requirement.

Egg hatching at higher temperature $\left(28-29^{\circ} \mathrm{C}\right)$ than in the norm showed that, incubation period lasted for 8-9 days, decreased by 1-2 days compared to moderate temperature, larva hatching finished in 2 days, it made the higher amount on the first day (60-62\%). But the amount of unhatched eggs was equal to $17,5-19,5 \%$, total amount of hatched larva was observed to decrease by $1,05-15,5 \%$.

The sharp difference in temperature and humidity affects not only the development of the silkworm during the incubation period, but also its survival during the larva period.

The breeds we are studying in our research are the most productive silkworm breeds of the People's Republic of China, which are considered as the main silkworm breeds in this country. We have achieved the following results by hatching high-yielding silkworm breeds and caring for young and old instar larva. For example, when the caterpillar is reared at $20-21^{\circ} \mathrm{C}$ temperature and $60-65 \%$ humidity, by the end of the fifth instar, its survival indication is $88,5 \%$ in the hybrids imported from China before cocoon spinning, while in local hybrids this rate is $90 \%$.

This means that the survival rate of caterpillar reared at low temperatures and humidity is almost the same. Their larva period duration lasted for 29-31 days, larva period of local caterpillar was found to decrease by 1-2 days. When the temperature and humidity in the cocoonery is moderate (temperature $26-27^{\circ} \mathrm{C}$, humidity $75-80 \%$ ), survival of larva hatched from imported eggs made average $92-94 \%$, it was noted that this rate is less by $1-3 \%$ than in local hybrids $(95,0 \%)$, while the larva period duration was the same as in control variant. Table 2 presents the related data.

Table 1

Hatching of imported silkworm eggs at different temperature and humidity (in 2015-2018)

\begin{tabular}{|c|c|c|c|c|c|c|c|c|c|c|}
\hline \multirow{2}{*}{$\begin{array}{l}\text { Silkworm breeds } \\
\text { and hybrids }\end{array}$} & \multirow{2}{*}{$\begin{array}{l}\text { Incuba- } \\
\text { tion } \\
\text { period } \\
\text { (day) }\end{array}$} & \multirow{2}{*}{$\begin{array}{l}\text { Amount } \\
\text { of the } \\
\text { first } \\
\text { larva, (\%) }\end{array}$} & \multicolumn{4}{|c|}{$\begin{array}{c}\text { Amount of hatched larva, } \\
\%\end{array}$} & \multirow{2}{*}{$\begin{array}{l}\text { Amount of } \\
\text { unhatched } \\
\text { larva (\%) }\end{array}$} & \multirow{2}{*}{$\begin{array}{l}\text { Hatching } \\
\text { of live } \\
\text { larva } \\
\text { (day) }\end{array}$} & \multirow{2}{*}{$\begin{array}{c}\text { Total } \\
\text { amount of } \\
\text { hatched } \\
\text { larva (\%) }\end{array}$} & \multirow{2}{*}{$\mathrm{Pd}$} \\
\hline & & & $\begin{array}{c}1- \\
\text { day }\end{array}$ & $\begin{array}{c}2- \\
\text { day }\end{array}$ & $\begin{array}{c}3- \\
\text { day }\end{array}$ & $\begin{array}{c}4- \\
\text { day }\end{array}$ & & & & \\
\hline \multicolumn{11}{|c|}{ At temperature $20-21^{\circ} \mathrm{C}$, humidity $60-65 \%$} \\
\hline "Yaponiya" breed & 14 & 4,0 & 20,5 & 30,5 & 20,5 & 14,0 & 10,5 & 5,5 & $89,5 \pm 0,15$ & - \\
\hline "Khitoy" breed & 13 & 4,5 & 23,0 & 28,5 & 22,0 & 13,0 & 9,0 & 5,0 & $91,0 \pm 0,20$ & - \\
\hline "Jigsong $\times$ Haoyue" & 13 & 2,5 & 33,5 & 34,5 & 16,0 & 6,5 & 7,0 & 4,5 & $93,0 \pm 0,14$ & - \\
\hline "Haoyue $\times$ Jigsong" & 13 & 2,5 & 31,0 & 36,0 & 15,0 & 7,5 & 8,0 & 5,0 & $92,0 \pm 0,19$ & - \\
\hline Ipakchi-1 $\times$ Ipakchi-2 & 13 & 2,0 & 34,5 & 36,5 & 16,0 & 6,0 & 7,0 & 4,5 & $93,0 \pm 0,20$ & - \\
\hline \multicolumn{11}{|c|}{ At temperature $24-25^{\circ} \mathrm{C}$, humidity $75-80 \%$} \\
\hline "Yaponiya" breed & 11 & 1,5 & 44,0 & 43,0 & 7,0 & - & 4,5 & 2,5 & $95,5 \pm 0,21$ & 0,999 \\
\hline "Khitoy" breed & 10 & 1,5 & 48,5 & 40,0 & 6,0 & - & 4,0 & 2,5 & $96,0 \pm 0,22$ & 0,998 \\
\hline "Jigsong $\times$ Haoyue" & 10 & 0,5 & 54,0 & 41,0 & 1,5 & 0,5 & 2,5 & 2,5 & $97,5 \pm 0,19$ & 0,999 \\
\hline "Haoyue $\times$ Jigsong" & 10 & 0,5 & 52,0 & 41,0 & 2,5 & 1,0 & 3,0 & 2,5 & $97,0 \pm 0,18$ & 0,996 \\
\hline Ipakchi-1 $\times$ Ipakchi-2 & 10 & 0,5 & 50,0 & 43,0 & 3,0 & - & 3,5 & 2,5 & $96,5 \pm 0,21$ & - \\
\hline \multicolumn{11}{|c|}{ At temperature $28-29^{\circ} \mathrm{C}$, humidity $70-75 \%$} \\
\hline "Yaponiya" breed & 9 & 5,5 & 48,5 & 25,5 & 1,0 & - & 19,5 & 2,0 & $80,5 \pm 0,16$ & - \\
\hline "Khitoy" breed & 8 & 5,0 & 50,5 & 24,0 & 1,5 & - & 19,0 & 2,0 & $81,0 \pm 0,15$ & - \\
\hline "Jigsong $\times$ Haoyue" & 8 & 4,5 & 62,0 & 14,0 & 2,0 & - & 17,5 & 2,0 & $82,5 \pm 0,18$ & - \\
\hline "Haoyue x Jigsong" & 8 & 3,0 & 62,0 & 16,0 & 1,0 & - & 18,0 & 2,0 & $82,5 \pm 0,17$ & - \\
\hline Ipakchi-1 x Ipakchi-2 & 8 & 6,5 & 60,0 & 14,0 & 1,0 & - & 18,5 & 2,0 & $81,5 \pm 0,17$ & - \\
\hline
\end{tabular}




\section{EPRA International Journal of Research and Development (IJRD)}

Volume: 5 | Issue: 11 | November 2020

- Peer Reviewed Journal

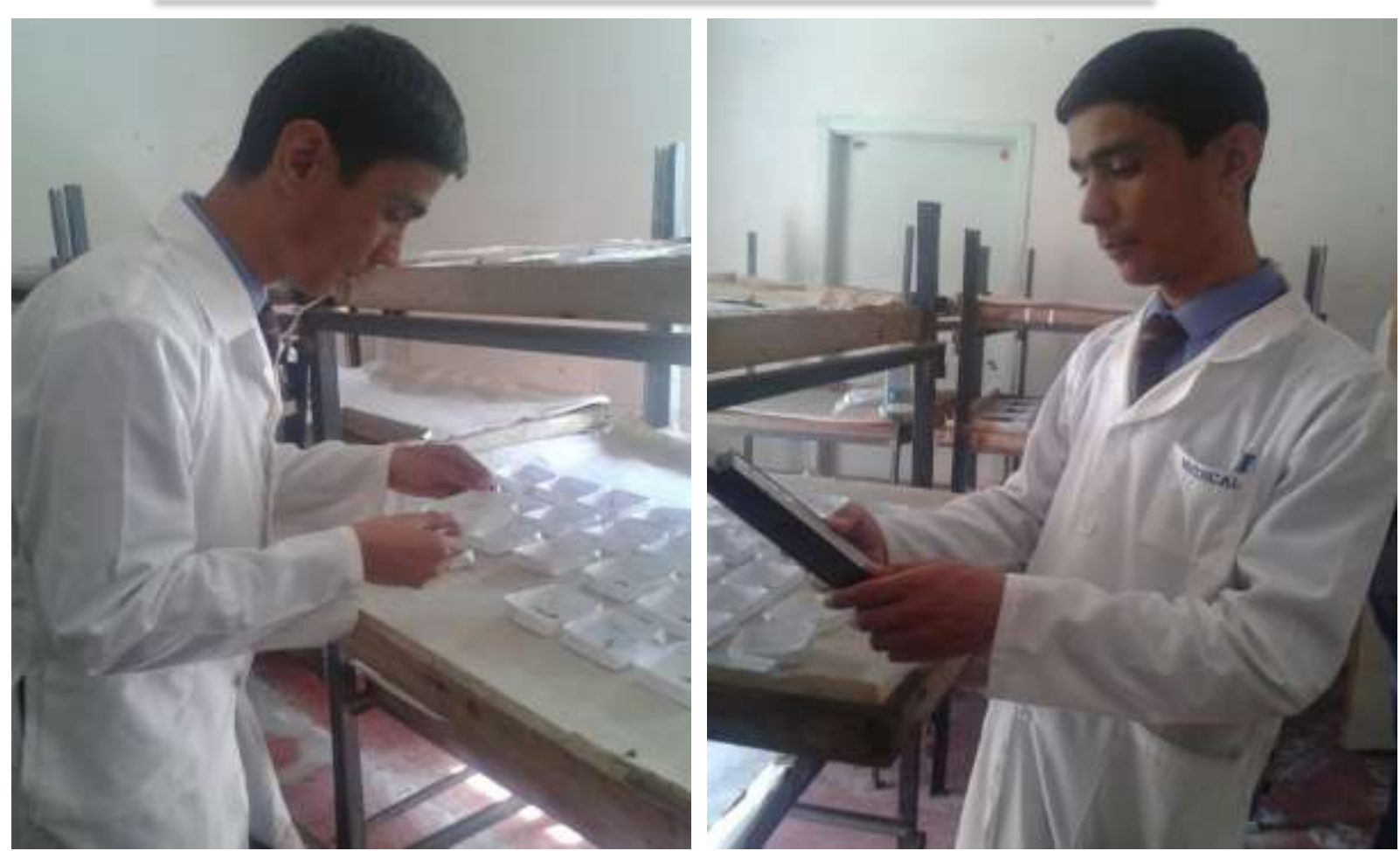

Figure 1. Egg hatching order of imported breeds and hybrids by variants

Table 2

Survival indicators of larva reared at different temperature and humidity (in 2015-2018)

\begin{tabular}{|c|c|c|c|c|c|c|c|c|}
\hline \multirow[b]{3}{*}{$\begin{array}{c}\text { Silkworm breeds and } \\
\text { hybrids }\end{array}$} & \multicolumn{7}{|c|}{ Number of larva by instar, pcs } & \multirow[b]{3}{*}{$\begin{array}{c}\text { Larva stage } \\
\text { duration, } \\
\text { days } M \pm M\end{array}$} \\
\hline & \multirow[b]{2}{*}{ 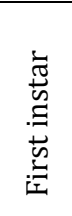 } & \multirow[b]{2}{*}{ 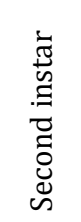 } & \multirow[b]{2}{*}{ 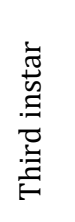 } & \multirow[b]{2}{*}{ 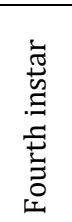 } & \multirow[b]{2}{*}{ 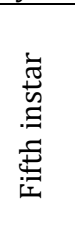 } & \multicolumn{2}{|c|}{ Prior to cocoon spin $M \pm M$} & \\
\hline & & & & & & Number & $\%$ & \\
\hline 1 & 2 & 3 & 4 & 5 & 6 & 7 & 8 & 9 \\
\hline \multicolumn{9}{|c|}{ At temperature $20-21^{\circ} \mathrm{C}$, humidity $60-65 \%$} \\
\hline "Yaponiya" breed & 200 & 187 & 182 & 178 & 176 & 175 & $87,5 \pm 0,33$ & $31 \pm 0,39$ \\
\hline "Khitoy" breed & 200 & 187 & 182 & 178 & 176 & 176 & $88,0 \pm 0,35$ & $31 \pm 0,35$ \\
\hline "Jigsong $\times$ Haoyue" & 200 & 186 & 181 & 179 & 178 & 177 & $88,5 \pm 0,28$ & $30 \pm 0,41$ \\
\hline "Haoyue $\times$ Jigsong" & 200 & 186 & 180 & 178 & 177 & 177 & $88,5 \pm 0,34$ & $30 \pm 0,37$ \\
\hline Ipakchi-1 × Ipakchi-2 & 200 & 189 & 185 & 183 & 181 & 180 & $90,0 \pm 0,23$ & $29 \pm 0,38$ \\
\hline \multicolumn{9}{|c|}{ At temperature $26-27^{\circ} \mathrm{C}$, humidity $75-80 \%$} \\
\hline "Yaponiya" breed & 200 & 196 & 193 & 188 & 184 & 184 & $92,0 \pm 0,26$ & $26 \pm 0,34$ \\
\hline "Khitoy" breed & 200 & 197 & 193 & 190 & 187 & 186 & $93,0 \pm 0,33$ & $25,5 \pm 0,31$ \\
\hline "Jigsong $\times$ Haoyue" & 200 & 195 & 192 & 190 & 188 & 188 & $94,0 \pm 0,31$ & $23 \pm 0,35$ \\
\hline "Haoyue $\times$ Jigsong" & 200 & 198 & 194 & 190 & 187 & 187 & $93,5 \pm 0,29$ & $23,5 \pm 0,38$ \\
\hline Ipakchi-1 $\times$ Ipakchi-2 & 200 & 198 & 196 & 194 & 191 & 190 & $95,0 \pm 0,23$ & $24 \pm 0,36$ \\
\hline \multicolumn{9}{|c|}{ At temperature $29-30{ }^{\circ} \mathrm{C}$, humidity $65-75 \%$} \\
\hline "Yaponiya" breed & 200 & 197 & 195 & 189 & 179 & 177 & $88,5 \pm 0,29$ & $24 \pm 0,38$ \\
\hline "Khitoy" breed & 200 & 198 & 196 & 191 & 185 & 183 & $91,5 \pm 0,32$ & $23,5 \pm 0,36$ \\
\hline "Jigsong $\times$ Haoyue" & 200 & 199 & 198 & 193 & 186 & 184 & $92,0 \pm 0,33$ & $22 \pm 0,37$ \\
\hline "Haoyue $\times$ Jigsong" & 200 & 199 & 198 & 194 & 191 & 186 & $93,0 \pm 0,30$ & $22,5 \pm 0,31$ \\
\hline Ipakchi-1 × Ipakchi-2 & 200 & 197 & 194 & 188 & 181 & 179 & $89,5 \pm 0,26$ & $22,5 \pm 0,33$ \\
\hline
\end{tabular}




\section{EPRA International Journal of Research and Development (IJRD)}

Volume: 5 | Issue: 11 | November 2020

- Peer Reviewed Journal

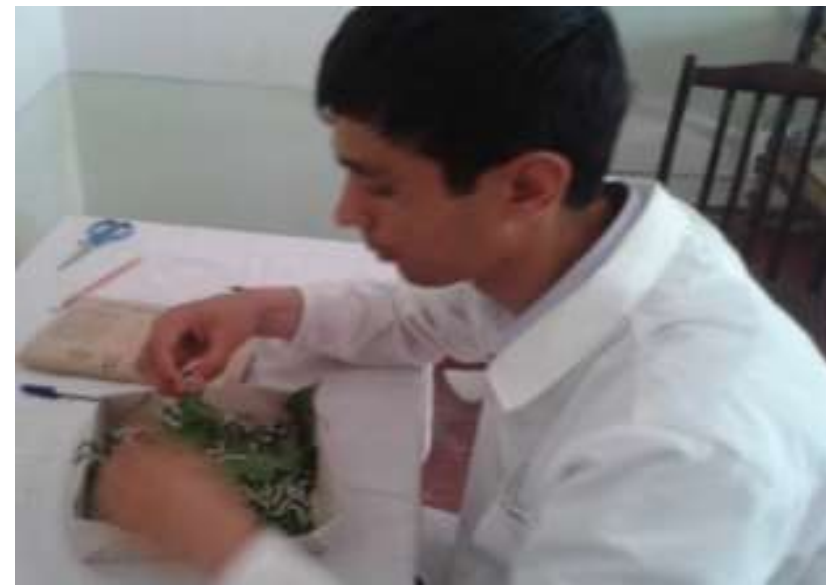

Figure 2. Determination of survival of imported silkworm breeds and hybrids

When silkworms were reared at high temperatures $\left(29-30^{\circ} \mathrm{C}\right)$, their survival averaged $89-93 \%$ in all variants, and the larva stage was found to be an average of 23-24 days.

The growth, development, and disease suffering of silkworms were also observed during the experiment. The larva developed well and healthy until the $3^{\text {rd }}$ instar in all variants. From the $4^{\text {th }}$ instar, it was found that they are mainly susceptible to bacterial and fungal diseases.

\section{CONCLUSION}

Analysing the results of research on the effect of sharply different temperatures and relative humidity of air on the hatching of silkworm eggs, the following conclusion can be drawn.

First, the fact that the temperature in the incubator is below normal during the period of egg revitalization slows down the embryonic development process in the egg and delays the larva hatching and the rearing period. During the incubation period, when the temperature exceeds the norm, the incubation period is shortened by one day, and larva hatching from eggs is reduced by $17.5-19.5 \%$. This is because high temperatures accelerate considerably the physiological, biochemical and metabolic processes in the egg. As a result, the normal development of the embryo is disrupted, and the hatched larva become weak and susceptible to disease. Therefore, when incubating eggs, it is advisable to have a temperature of $24-25^{\circ} \mathrm{C}$ and a humidity of $75-80 \%$.

Second, the percentage of revitalization and hatching of eggs of imported silkworm breeds and hybrids does not exceed that of local eggs. Therefore, we recommend using local silkworm eggs without incurring additional costs (foreign seeds are two to three times more expensive), and instead of spending money on eggs from abroad to spent on silkworm breeding enterprises in the Republic.

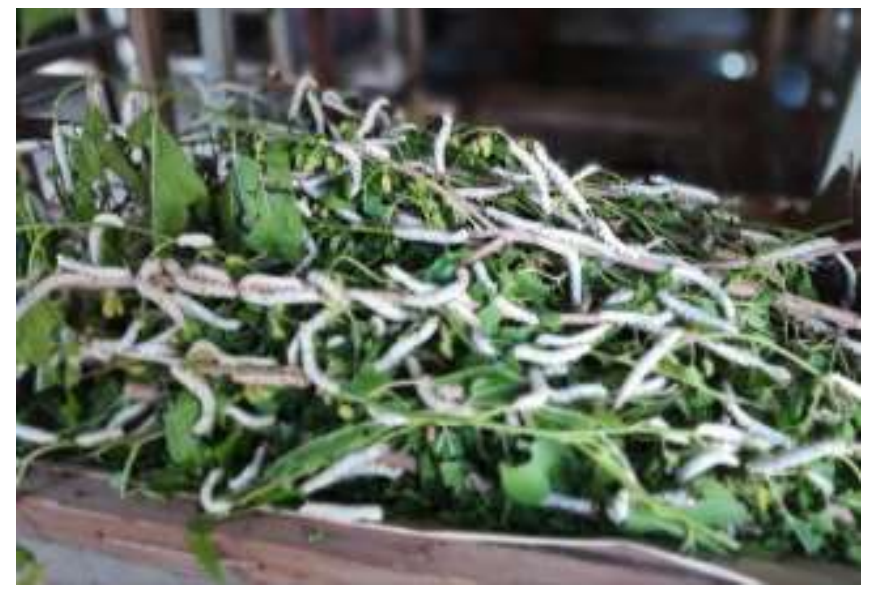

Figure 3. Feeding and care for imported silkworm breeds and hybrids

It was defined that when larvae from imported eggs were fed at low $\left(20-21^{\circ} \mathrm{C}\right)$ and above normal (29$30^{\circ} \mathrm{C}$ ) temperatures, the survival of the larvae decreased by $5-6 \%$ and the larva stage prolonged to 7-9 days. This case causes the silkworms to be left to feed on hot summer days. As a result, due to the roughing and hardening of the leaves, the caterpillars are not fed enough and spin small and poor quality cocoons. Having considered all of this, it can be concluded that it is advisable to keep the imported eggs at a temperature of at $24-25^{\circ} \mathrm{C}$ to hatch, and to rear young larva at a temperature of $26-27^{\circ} \mathrm{C}$ and $75-80 \%$ humidity, and the adult larva at a temperature of $25-26^{\circ} \mathrm{C}$ and $70-75 \%$ humidity.

\section{REFERENCES}

1. Decree of the President of the Republic of Uzbekistan "About Actions strategy for further development of the Republic of Uzbekistan" from February 7, 2017, numbered PD-4947. - Tashkent, 2017.

2. Decree of the President of the Republic of Uzbekistan "About the measures on establishment of activity of the association "Uzbekipaksanoat"” from March 29, 2017, numbered PD-2856. - Tashkent, 2017. pp.1-5.

3. Decree of the President of the Republic of Uzbekistan "About the additional measures on further development of sericulture sector" from March 20, 2018, numbered PD-3616. - Tashkent, 2018. pp.1-4.

4. Akhmedov N.A. (1992). Egg hatching of silkworm. Tashkent, pp. 6-7.

5. Akhmedov N.A. (1998). The effect of contrast temperature and humidity on silkworm egg hatching. Silk. Tashkent, 1998. №4. pp. 22-23.

6. Bekkamov Ch. (2008). The effect of sharply changable temperature and humidity on survival of silkworm. Republican scientific-practical conference materials. Tashkent. pp. 124-127.

7. Umarov Sh.R. (2004). The effect of rearing pure quality silkworms by new technology in summer and autumn on biological indicators of cocoon. Scientific 
basis for solving current problems in the field of silkworm breeding. Tashkent. pp. 208-214.

8. Umarov Sh.R., Nasirillaev B.U., Giyasova K.S. (2016).

Influence of selection of breeding cocoons by their compactness on silkworm embryonic and postembryonic viability. Uzbekistan agriculture. Tashkent, №8. pp. 41-42.

9. Umarov Sh.R., Nasirillaev B.U., Giyasova K.S. (2017). Comparative analysis of vitality and productivity traits of silkworm in elite population made by a new method. Zooveterinary, №5. pp.39-40. 